\title{
Root Respiratory Characteristics of 'Rotundifolia' Holly under Supraoptimal Temperatures
}

\author{
John M. Ruter' and Dewayne L. Ingram² \\ Department of Environmental Horticulture, WAS, Gainesville, FL 32611 \\ Additional index words. heat stress, CN-sensitive pathway, CN-resistant respiration, Japanese holly, Ilex crenata
}

Abstract. Respiration of excised Ilex crenata (Thunb.) 'Rotundifolia' roots as influenced by root-zone growth temperature and buffer solution temperature was measured in the presence and absence of salicylhydroxamic acid (SHAM) and potassium cyanide (KCN). Respiration rates of roots excised from plants grown for 3 weeks with rootzones at 30, 34, 38, or 42C decreased linearly with increased root-zone growth temperatures when the buffer solution was maintained at $25 \mathrm{C}$. When the buffer solution was the same temperature as the root growth temperature, respiration rates were similar. Respiration in roots from plants grown with the root zone at $30 \mathrm{C}$ was maximal with the buffer solution at $34 \mathrm{C}$ and decreased to a minimum at $46 \mathrm{C}$. Above $46 \mathrm{C}$, a presumably extra-mitochondrial stimulation of $\mathrm{O}_{2}$ consumption occurred. The activity of the $\mathrm{CN}$-resistant pathway was fully engaged $\left(P^{\prime}=0.99\right)$ when roots were grown at $30 \mathrm{C}$ and buffer solution was at $25 \mathrm{C}(30-25)$. $\mathrm{CN}$-resistant pathway activity decreased with 'the buffer solution at $46 \mathrm{C}$.

High root-zone temperatures are known to have profound effects on growth, assimilate partitioning, and respiratory mechanisms of plants (Cooper, 1973). Root growth is often retarded by temperatures in excess of $30 \mathrm{C}$, with cessation of top growth or necrosis occurring at 40C or above (Wong et al., 1971). Decreases in root dry weight (Barr and Pellett, 1972) and root growth (Johnson and Ingram, 1984) have been reported for several woody species exposed to root-zone temperatures above 40C.

Temperatures as high as $45 \mathrm{C}$ have been shown to increase respiration rates of actively growing tissues (Janes et al., 1988; Levitt, 1980). Temperature can have significant effects on the maintenance costs of plant cells (Penning de Vries, 1975). Dark and maintenance respiration have a $\mathrm{Q}_{10}$ of two or more in a variety of plants as temperature increases (Hunt and Loomis, 1979; McKree, 1974). Respiration rate increases initially in response to supraoptimal root-zone temperatures, but decreases over time due to the progressive degradation of enzymatic processes (Langridge and McWilliam, 1967). Janes et al. (1988) found respiration rates in cultured tomato roots to be highest between 40 and $45 \mathrm{C}$ after a 30-min exposure, which suggests that respiratory enzymes are functioning at supraoptimal temperatures.

Temperature differentially affects the electron transport pathways of plant mitochondria (Dizengremel and Chauveau, 1978). Two mitochondrial electron transport terminal oxidases are known, cytochrome c oxidase, which is cyanide-sensitive (CN-sensitive), and the less-understood alternative oxidase, which is $\mathrm{CN}$ resistant. The $\mathrm{CN}$-resistant pathway in plant mitochondria is considered to be an alternative, nonphosphorylating pathway that branches from the respiratory chain at ubiquinone (Henry and Nyns, 1975). Salicylhydroxamic acid (SHAM) is a substituted hydroxamic acid that specifically inhibits the CN-resistant pathway in isolated mitochondria and can be used to assess Unresistant respiration (Schonbaum et al., 1971). Although concentrations of SHAM up to $25 \mathrm{~mm}$ can be used to estimate the

Received for publication 8 Dec. 1989. Florida Expt. Sta. J. Ser. no. R-00291. The cost of publishing this paper was defrayed in part by the payment of page charges. Under postal regulations, this paper therefore must be hereby marked advertisement solely to indicate this fact.

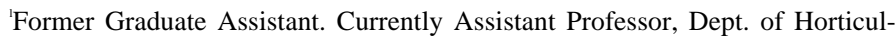
ture, Coastal Plain Experiment Station, Tifton, GA 31793.

'Currently Chairman and Professor, Dept. of Horticulture and Landscape Architecture, Univ. of Kentucky, Lexington, KY 40546. activity of the CN-resistant pathway in plant tissue (Lambers et al., 1983), SHAM has been shown to stimulate $0_{2}$ consumption in roots (de Visser and Blaquiere, 1984; Spreen Brouwer et al., 1986). The stimulation of $\mathrm{O}_{2}$ consumption at low SHAM concentrations $(\leq 5 \mathrm{~mm})$ is believed to be caused by a CN-sensitive peroxidase (Spreen Brouwer et al., 1986; van der Plas et al., 1987). The CN-resistant pathway is engaged under a variety of environmental stresses. In leaves of Fatsia japonica the CNresistant respiratory pathway functioned between 6 to $30 \mathrm{C}$, but declined significantly with temperatures up to 40C (Burgos et al., 1987).

Working with Ilex crenata 'Rotundifolia', Foster (1986) found root respiration to increase after 7 days with root-zone temperatures up to $40 \mathrm{C}$. Although total $\mathrm{CO}_{2}$ respired from 'Rotundifolia' holly roots was not influenced by increasing root-zone temperature up to $42 \mathrm{C}$, increases in respiration of current photoassimilates at 38C were detected (Ruter and Ingram, 1990). Increased respiration can affect long-term plant growth and vigor in reaction to supraoptimal root-zone temperatures. Our studies with 'Rotundifolia' holly were conducted to determine: 1) the effect of high temperatures on respiratory rates of roots grown at ambient (25C) or supraoptimal root-zone temperatures, and 2) the effect of high temperature on the function of the $\mathrm{CN}$ resistant and $\mathrm{CN}$-sensitive respiratory pathways.

\section{Materials and Methods}

Rooted stem-tip cuttings of Ilex crenata 'Rotundifolia' were potted in 1200-ml clear plastic bags using $1000 \mathrm{~cm}^{3}$ of MetroMix 300 (W.R. Grace, Cambridge, Mass.). Plants were grown in a glass greenhouse under natural daylength conditions for a minimum of 12 weeks before being transferred to a high-light growth room 3 weeks before the initiation of each experiment.

Experiments were conducted in a $3.0 \times 7.6 \mathrm{~m}$ walk-in growth room with irradiance supplied by eighteen $1000-\mathrm{W}$ phosphorcoated metal-arc HID lamps (GTE Sylvania, Manchester, N.H.). Photosynthetic photon flux density as measured with a quantum radiometer (LI-COR, Lincoln, Neb.) was $500 \mu \mathrm{mol} \cdot \mathrm{s}^{-1} \cdot \mathrm{m}^{-2}$ at canopy height. The photoperiod was $13 \mathrm{hr}$ daily (0700 to 2000 HR) with the dark period being interrupted for $3 \mathrm{hr}$ (2200 to $0100 \mathrm{HR}$ ) with incandescent light. The air was maintained at 28 $\pm 1 \mathrm{C}$ during the light period and $21 \pm 1 \mathrm{C}$ during the dark period. Relative humidity was maintained at $\approx 40 \%$ during the light period and $90 \%$ during the dark period. Plants were fertilized twice weekly with solution that contained $300 \mathrm{mg} \mathrm{N} / \mathrm{liter}$ 
(5.6\% nitrate, $4.0 \%$ ammonium, $10.4 \%$ urea) from soluble $20 \mathrm{~N}$ 8.8P-16.6K fertilizer (Peters 20-20-20, W.R. Grace).

Two experiments were designed to evaluate the effects of temperature on respiration in roots of 'Rotundifolia' holly. In expt. 1, the plants were grown with the root-zone at 30, 34, 38 , or $42 \mathrm{C}$ for $6 \mathrm{hr}$ daily ( $28 \pm \mathrm{IC}$ base temperature) for 3 weeks before respiration of excised roots was measured in buffer solution corresponding to the growth temperature $(30,34,38$, or $42 \mathrm{C}$ ) or at $25 \mathrm{C}$. Also, plants were grown with the root-zone at $30 \mathrm{C}$, and respiration measurements were made at buffer solution temperatures of 25 to 70C. For expt. 2, effects of temperature" on the CN-resistant respiratory pathway and the $\mathrm{CN}$ sensitive pathway were determined for the same treatments as in expt. 1 and from 25 to $54 \mathrm{C}$ using different root tissue samples. For all experiments, root-zone temperature treatments were imposed for 21 days in a completely randomized block design replicated with a minimum of five plants per treatment. Rootzone temperatures were maintained within $\pm 1 \mathrm{C}$ using an electronically controlled root-heating system described by Foster (1986).

Respiratory measurements were made with a Clark-type oxygen electrode (Hansatech, Kings Lynn, England). The temperature of the reaction vessel was maintained by circulating heated water through the water jacket. The buffer solution consisted of $0.3 \mathrm{M}$ mannitol and $25 \mathrm{~mm}$ Tes buffer adjusted to $\mathrm{pH} 7.1$ with $\mathrm{KOH}$ plus appropriate concentrations of $\operatorname{SHAM}(0,5,10$, and $15 \mathrm{~mm})$ and $\mathrm{KCN}(0,0.5$, and $1.0 \mathrm{~mm})$ when used. Samples $(100 \mathrm{mg}$ ) of uniform, fibrous white lateral roots $\approx 1.0 \mathrm{~cm}$ long were used. Root samples were pooled from a minimum of three plants per root-zone temperature treatment and were kept moist (maximum period of 10 rein) until measurements were made. Rates of $\mathrm{O}_{2}$ uptake were determined between 8 and 10 min after steady state uptake was achieved and were expressed on the basis of root fresh weight.

$\mathrm{V}_{\text {res }}$ is that portion of $\mathrm{V}_{\mathrm{T}}$ (total respiration) that is insensitive to inhibitors of the $\mathrm{CN}$-sensitive and $\mathrm{CN}$-resistant pathways and is considered to be extra-mitochondrial. The activity of the $\mathrm{CN}$ resistant alternative pathway was determined using the method described by Lambers et al. (1983). Effects of SHAM on the $\mathrm{CN}$-sensitive cytochrome pathway were determined by reverse titration of roots with $\mathrm{KCN}$ in the presence and absence of SHAM (de Visser and Blacquiere, 1984; Lambers and Day, 1987; Theologis and Laties, 1978).

Electrolyte leakage procedures for the determination of a critical temperature for 'Rotundifolia' holly roots were performed as described by Ingram and Buchanan (1981). Excised roots (1g samples) were placed in test tubes and exposed for $30 \mathrm{~min}$ to temperatures ranging from 30 to $55 \mathrm{C}$ in a thermostatically controlled circulating polyethylene glycol bath. Twenty-five milliliters of deionized water were added to each sample before ice bath incubation for $24 \mathrm{hr}$. Conductivity of the incubation solution was determined and the samples were killed by autoclaving at $120 \mathrm{C}$ for $20 \mathrm{~min}$. Samples were incubated for $24 \mathrm{hr}$ before the final conductivity reading was taken. Electrolyte leakage was expressed as the ratio of incubation solution conductivity after treatment to the conductivity after autoclaving. Data for all experiments were analyzed as a general linear model (SAS Institute, Cary, N.C.), unless otherwise noted.

\section{Results and Discussion}

Effects of temperature on respirator rate. When the plants were grown with root zone at 30 to $42 \mathrm{C}$ and $\mathrm{O}_{2}$ consumption was determined at $25 \mathrm{C}$, respiration rate decreased linearly with increasing root-zone growth temperature $\left[R^{2}=0.98\right.$, VT $=$ 0.189-0 .0033 (Temp)] (Fig. 1). However, root-zone temperatures did not affect respiration rate when the buffer solution temperature was equal to the growth temperature. The volubility of $\mathrm{O}_{2}$ decreases with increasing buffer solution temperature and could potentially limit respiration. These results showed that decreased respiration was due to root-zone growth temperature and not to decreased $\mathrm{O}_{2}$ availability. Solution temperature up to $42 \mathrm{C}$ did not adversely affect respiration rates due to decreasing $\mathrm{O}_{2}$ levels in the buffer solution.

In Agave deserti, a succulent desert perennial, root respiration increased several fold from 5 to $40 \mathrm{C}$ and decreased 2-fold as temperature increased from 45 to 55C (Palta and Nobel, 1989). Increased respiration rates up to $45 \mathrm{C}$ have generally been attributed to increased maintenance respiration and/or changes in enzyme activation energy relative to changes in temperature. Variation in respiration rates at different buffer solution temperatures (Temp/Temp at 38 and $42 \mathrm{C}$ vs. Temp/25 at 38 and 42C) in expt. 1 (Fig. 1) may be due to increased maintenance respiration costs when the roots were exposed to higher buffer solution temperatures. Maintenance respiration increases with increasing temperature to produce energy for maintaining cellular structure and ion gradients and for making physiological adaptations necessary to maintain cellular integrity in changing environments.

Enzyme-catalyzed reactions are sensitive to small changes in temperature in the biologically active range. Many enzymes are labile in the range of 40 to $50 \mathrm{C}$. Above an optimum temperature, catalytic effectiveness decreases due to enzyme inactivation or denaturation. Root respiration in 'Rotundifolia' holly increased when plants were exposed to temperatures up to 40C for 1 week (Foster, 1986). The decrease in respiration at $25 \mathrm{C}$ when root-zone growth temperatures were maintained for 3 weeks at 30 to $42 \mathrm{C}$ possibly may be explained by the loss of catalytic effectiveness of certain respiratory enzymes after repeated, prolonged exposure to elevated temperatures. The elevated respiratory rates during growth at 38 or $42 \mathrm{C}$ when the buffer solution

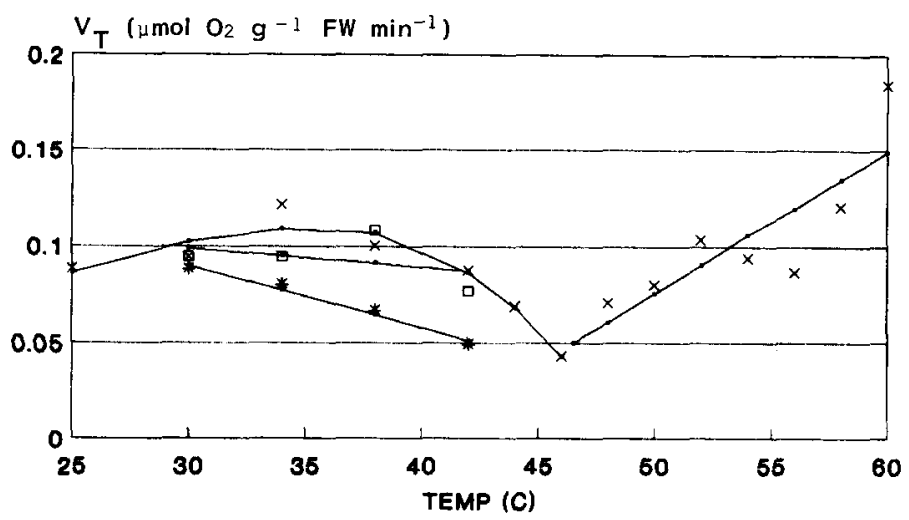

Fig. 1. Inflüence of root-zone growth temperature and buffer solution temperature combinations on the respiratory rate $\left(\mathrm{V}_{\mathrm{T}}\right)$ of Ilez crenata 'Rotundifolia' roots. Temp/25 $\left(*, R^{2}=0.98\right)$ indicates plants were grown with their root zone at $30,34,38$, or $42 \mathrm{C}$ and respiration was measured at $25 \mathrm{C}$. Temp/Temp $\left(\square, R^{2}=0.65\right)$ indicates plants were grown and respiration measurements were made at the same temperature. 30/Temp $(x)$ indicates plants were grown with their root-zone at $30 \mathrm{C}$ and respiration was measured at and is shown for different temperatures ( 25 to $60 \mathrm{C}$ ). Respiration rates from 25 to $46 \mathrm{C}$ responded quadratically $\left(R^{2}=0.94\right)$ while rates from 46 to $60 \mathrm{C}$ responded linearly $\left(R^{2}=0.76\right)$. Each value represents the mean of six independent determinations. 
was also 38 or $42 \mathrm{C}$, respectively, could be due to decreased activation energy requirements at the buffer solution temperatures noted when compared to the requirements at $25 \mathrm{C}$.

Two responses were seen as roots grown at 30C were exposed for $10 \mathrm{~min}$ to buffer solutions held in the range of 25 to $60 \mathrm{C}$ (Fig. 1). A quadratic response described the relationship of respiration to temperature in the range of 25 to $46 \mathrm{C}[\mathrm{Pr}>\mathrm{F}=$ $0.01, R^{2}=0.94, \mathrm{VT}=0.3559-0.0349(\mathrm{Temp})+0.0014$ $(\mathrm{Temp})^{2}$ ]. Maximum $\mathrm{O}_{2}$ consumption occurred at $34 \mathrm{C}(0.121$ $\left.\mu \mathrm{mol} \cdot \mathrm{min}^{-1} \cdot \mathrm{g}^{-1} \mathrm{FW}\right)$ while respiration decreased by $\approx 50 \%$ at $46 \mathrm{C}$ in relation to the rate at $25 \mathrm{C}$. Consumption of $\mathrm{O}_{2}$ increased linearly in the range of 46 to $60 \mathrm{C}\left[\mathrm{Pr}>\mathrm{F}=0.01, R^{2}=0.76\right.$, $\mathrm{V}_{\mathrm{T}}=-0.2965+0.0074$ (Ternp)]. Variation in $\mathrm{O}_{2}$ consumption values $>54 \mathrm{C}$ may have been due to degeneration of root tissue. At 65 and $70 \mathrm{C}, \mathrm{O}_{2}$ consumption $(0.057$ and 0.032 $\mu \mathrm{mol} \cdot \mathrm{min}^{-1} \cdot \mathrm{g}^{-1} \mathrm{FW}$, respectively) decreased below the control value $\left(0.088 \mu \mathrm{mol} \cdot \mathrm{rnin}^{-1} \cdot \mathrm{g}^{-1} \mathrm{FW}\right)$.

Consumption of $\mathrm{O}_{2}$ in the range of 25 to $46 \mathrm{C}$ was probably due to mitocliondrial respiratory processes, while increased $\mathrm{O}_{2}$ consumption at temperatures $>46 \mathrm{C}$ may have been be due to lipid oxidation caused by peroxidases (Levitt, 1980). Peroxidases are extremely heat-stable enzymes that have been implicated in the SHAM stimulation of $\mathrm{O}_{2}$ uptake in intact roots of several species (de Visser and Blacquiere, 1984; Spreen Brouwer et al., 1986). Electrolyte leakage procedures have been shown to be an effective method for determining supraoptimal , temperature thermostability of woody plant roots (Ingram and Buchanan, 1981). Lethal temperatures for. woody plant roots can be determined from the midpoint of a sigmoidal response curve of electrolyte leakage vs. temperature (Ingram and $\mathrm{Bu}-$ chanan, 1984). The lethal temperature of 'Rotundifolia' holly roots was predicted to be $48 \pm 1.5 \mathrm{C}$ for a 30 -min exposure as determined by electrolyte leakage (Fig. 2). This lethal temperature corresponds with the temperature initiating an increase in $\mathrm{O}_{2}$ consumption (46 to $48 \mathrm{C}$ ). Baaziz (1989) found that a 20min exposure to $60 \mathrm{C}$ did not completely inactivate all peroxidase isozymes from date palm leaves. In preliminary studies, 'Rotundifolia' holly roots exposed to 44 to $60 \mathrm{C}$ for $10 \mathrm{~min}$ in buffer solution continued $\mathrm{O}_{2}$ consumption after the roots were removed. In barley roots, peroxidase was easily washed from the roots but was not active unless exogenous NADH was added

* electrolyte leakage

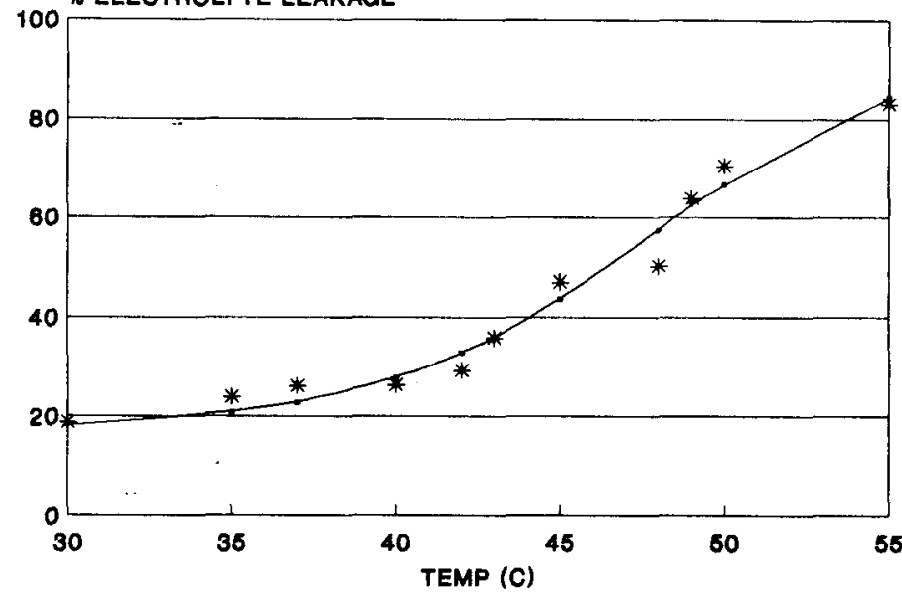

Fig. 2. Electrolyte leakage from excised roots of 'Rotundifolia' holly after a 30-min exposure to temperatures in the range of 30 to $55 \mathrm{C}$. The critical temperature $(48.0 \pm 1.5 \mathrm{C})$ was determined from a fitted sigmoidal curve as described by Ingram and Buchanan (1984). Each point is the mean of eight replications.
(Bingham and Farrar, 1987). Since an apparent loss of membrane integrity occurs in 'Rotundifolia' holly near 48C, reductants such as NADH necessary for the functioning of a peroxidase may have leaked out into the buffer solution above $46 \mathrm{C}$.

Effect of temperature on the $\mathrm{CN}$-sensitive and $\mathrm{CN}$-resistant pathways. The effect of inhibitor concentrations on root respiration was determined for plants grown with the root-zone at $30 \mathrm{C}$, but measuring respiration in a buffer solution at $25 \mathrm{C}$. Maximum inhibition of respiration (66\% decrease) occurred with $1.0 \mathrm{~mm} \mathrm{KCN}$ and $15.0 \mathrm{~mm}$ SHAM. SHAM alone (15.0 mM) decreased respiration $\left(\mathrm{V}_{\mathrm{T}}\right)$ by $\approx 40 \%$ while residual respiration $\left(\mathrm{V}_{\text {res }}\right)$ accounted for $33 \%$ of total respiration. The inhibition caused by SHAM indicates the $\mathrm{CN}$-resistant pathway was engaged in vivo in holly roots (Moller et al., 1988). Potassium cyanide, the inhibitor of the $\mathrm{CN}$-sensitive cytochrome pathway, decreased respiration by $\approx 22 \%$ at $1.0 \mathrm{~mm}$ The $p$ values (slope of the resulting regression relationship) obtained by reverse filtration for $\mathrm{KCN}$ at 0.5 and $1.0 \mathrm{~mm}$ were 1.48 and 1.05 , respectively. According to de Visser and Blacquiere (1984), a $p$ value $>1$ indicates that SHAM inhibits the flow of electrons through the $\mathrm{CN}$-sensitive cytochrome pathway. When $p=1$, SHAM had no effect on the cytochrome pathway. Accordingly, the concentrations of SHAM used in this study could be used in conjunction with $1.0 \mathrm{~mm} \mathrm{KCN}$ to inhibit the cyanide-resistant pathway in 'Rotundifolia' holly roots since $p$ at $1.0 \mathrm{~mm} \mathrm{KCN}$ was not different from 1.

Percent SHAM inhibition ranged from a low of $26.7 \%$ for the 30/40C (root-zone growth temperature - buffer solution temperature) treatment to a high of $58.7 \%$ for the $30 / 25 \mathrm{C}$ treatment (Table 1). That portion of respiration resistant to $\mathrm{KCN}$ (percent $\mathrm{CN}$ resistance) ranged from a high of 93.3\% (30/46C) to a low of $53.9 \%(42 / 42 \mathrm{C})$. Lambers et al. (1983) reported a range of $0 \%$ to $44 \%$ SHAM inhibition and $32 \%$ to $64 \% \mathrm{CN}$ resistance for intact roots of several agronomic annual species. Residual respiration $\left(\mathrm{V}_{\text {res }}\right)$ accounted for up to $40 \%$ of total respiration in crowns of frost-sensitive and frost-tolerant winter wheat cultivars (Rybka, 1989). Lambers and Day (1987) noted that residual respiration rarely exceeds $10 \%$ in roots. In our study, residual respiration ranged from a low of $27.9 \%$ (34/ $25 \mathrm{C})$ to a high of $70.4 \%$ (30/46 C). This high degree of residual respiration indicates the presence of extra-mitochondrial oxidases that are resistant to both SHAM and $\mathrm{KCN}$ or, else, poor penetration of inhibitors into the roots. Large residual respiration values in certain tissues may be caused by poor penetration of inhibitors into certain parts of tissues (Lambers and Day, 1987). Greater suberization in 'Rotundifolia' holly root segments compared to succulent root tips used in other studies could have decreased inhibitor penetration and may have accounted for some of the variation obtained in this study (Table 1). Oxygen consumption did not increase at low concentrations of SHAM for intact holly roots in our study, thus indicating that peroxidases were not stimulated.

The activity of $\mathrm{CN}$-resistant respiration $\left(P^{\prime}\right)$, as calculated from the ratio of SHAM inhibition divided by $\mathrm{CN}$ resistance (Lambers et al., 1983), was fully activated $\left(P^{\prime}=0.99\right)$ in plants grown with the root zone at $30 \mathrm{C}$ when respiration was measured in buffer solution at $25 \mathrm{C}$. No differences in CN-resistant pathway activity were detected when the temperatures of the root growth zone and of the buffer solution were the same. When the buffer solution was maintained at $25 \mathrm{C}$, the 34 and $38 \mathrm{C}$ rootzone treatments exhibited decreased $\mathrm{CN}$-resistant pathway activity compared to the control (30C).

In leaves of Fatsia japonica, the capacity of the CN-resistant 
Table 1. Effects of root-zone temperature and increasing buffer solution temperature on the $\mathrm{CN}$-sensitive and $\mathrm{CN}$-resistant respiratory pathways in holly roots. Activity of $\mathrm{CN}$-resistant respiration $\left(P^{\prime}\right)$ was calculated as the ratio of (SHAM inhibition)/(CN-resistance). Values presented are the means $\pm \mathrm{SE}$ of at least five independent determinations. The concentrations of effecters used were: SHAM (15 mM) and KCN (1.0 mM).

\begin{tabular}{cccccc}
\hline \hline $\begin{array}{c}\text { Growth } \\
\left({ }^{\circ} \mathrm{C}\right)\end{array}$ & $\begin{array}{c}\text { Buffer } \\
\left({ }^{\circ} \mathrm{C}\right)\end{array}$ & $\begin{array}{c}\text { S H A M } \\
\text { inhibition } \\
(\%)\end{array}$ & $\begin{array}{c}\text { CN resistance } \\
(\%)\end{array}$ & $P^{\prime}$ & $\mathrm{V}$ \\
\hline 30 & 30 & $35.7(10.9)$ & $57.0(2.4)$ & $0.63(0.21)$ & $39.8(2.4)$ \\
34 & 34 & $34.0(12.6)$ & $58.7(11.2)$ & $0.58(0.22)$ & $35.6(8.5)$ \\
38 & 38 & $28.7(9.8)$ & $60.2(13.0)$ & $0.48(0.20)$ & $39.5(4.5)$ \\
42 & 42 & $35.5(6.1)$ & $53.9(6.1)$ & $0.66(0.20)$ & $42.9(4.5)$ \\
30 & 25 & $58.7(6.1)$ & $59.0(8.3)$ & $0.99(0.19)$ & $34.3(8.9)$ \\
34 & 25 & $27.4(5.2)$ & $41.3(2.1)$ & $0.67(0.12)$ & $27.9(5.6)$ \\
38 & 25 & $39.4(9.2)$ & $62.1(8.1)$ & $0.63(0.14)$ & $44.0(8.9)$ \\
42 & 25 & $38.8(8.5)$ & $55.1(8.8)$ & $0.70(0.32)$ & $33.8(4.0)$ \\
30 & 25 & $58.7(6.1)$ & $59.0(8.3)$ & $0.99(0.19)$ & $34.3(8.9)$ \\
30 & 30 & $35.7(10.9)$ & $57.0(2.4)$ & $0.63(0.21)$ & $39.8(2.4)$ \\
30 & 34 & $50.4(7.2)$ & $61.4(8.3)$ & $0.82(0.22)$ & $41.6(3.4)$ \\
30 & 38 & $37.5(5.2)$ & $59.6(6.7)$ & $0.63(0.17)$ & $48.0(6.5)$ \\
30 & 42 & $38.5(11.1)$ & $66.1(8.3)$ & $0.69(0.23)$ & $53.2(5.1)$ \\
30 & 46 & $26.7(11.4)$ & $93.3(6.4)$ & $0.29(0.12)$ & $70.4(6.4)$ \\
30 & 50 & $42.3(5.0)$ & $63.9(8.8)$ & $0.66(0.16)$ & $40.5(5.8)$ \\
30 & 54 & $39.0(5.8)$ & $79.0(7.7)$ & $0.49(0.20)$ & $52.3(7.8)$ \\
\hline
\end{tabular}

pathway was high between 6 and 30C (0.81 to 0.98$)$ and declined significantly at 36 and 40C (Burgos et al., 1987). In our study, the activity of the CN-resistant pathway was fully engaged at $25 \mathrm{C}$, ranged from $63 \%$ to $82 \%$ activation between 30 to $42 \mathrm{C}$ and decreased to $29 \%$ activation at $46 \mathrm{C}$ when roots were grown at $30 \mathrm{C}$ and then exposed to the higher buffer solution temperatures. Several authors have proposed that decreased $\mathrm{O}_{2}$ availability at high temperatures due to decreased $\mathrm{O}_{2}$ volubility may explain why the alternative pathway accounts for a greater portion of total respiration at low than at higher temperatures (Cook and Cammack, 1985; McCaig and Hill, 1977; Purvis, 1988). Temperature did not have a significant effect on the activity of the $\mathrm{CN}$-resistant pathway at buffer solution temperatures up to $46 \mathrm{C}$, indicating that decreased $\mathrm{O}_{2}$ volubility with increasing temperature did not limit respiratory functions during this short exposure period. The decrease in CN-resistant pathway activity at $46 \mathrm{C}$ corresponds to a decrease in SHAM inhibition and an increase in $\mathrm{CN}$ resistance $(93.3 \%)$ ). These differences may also be due to thermal effects on the oxidases themselves or temperature-induced alterations in membrane structure. The loss of CN-resistant activity at $46 \mathrm{C}$ corresponded to the temperature $(48 \pm 1.5 \mathrm{C})$ disrupting holly root membranes, thus leading to the disorganization of the electron transport system. We speculate that the "recovery" of activity at 50C was due to an uncharacterized oxidase that appeared to be stimulated by temperatures $>46 \mathrm{C}$.

Kiener and Bramlage (1981) have proposed that the CN-resistant pathway serves a protective role against temperature extremes, functioning in reserve in case of failure of the more sensitive $\mathrm{CN}$-sensitive pathway. Since activity did not differ for $\mathrm{CN}$-resistant pathway activity in the range of 25 to $42 \mathrm{C}$, we conclude that engagement of the $\mathrm{CN}$-resistant pathway did not depend on exposure to temperature extremes. Lambers (1982) suggested that the $\mathrm{CN}$-resistant pathway functions as an "energy overflow" that removes excess carbohydrates when substrate levels in the cell are high and the need for carbon skeletons and ATP is low. de Visser et al. (1986) proposed the concept of the
CN-resistant pathway acting as an "overcharge overflow", where under circumstances of increased cellular need for ATP, the CNresistant pathway would be engaged as an inefficient method for supplementing ATP produced through the cytochrome pathway. Further research would be required before the views of Lambers (1982) or de Visser et al. (1986) could be distinguished relative to the respiratory response of the $\mathrm{CN}$-resistant pathway to increasing root-zone temperature in 'Rotundifolia' holly.

\section{Literature Cited}

Baaziz, M. 1989. The activity and preliminary characterization of peroxidases in leaves of cultivars of date palm, Phoenix dactylifera L. New PhytoL 111:403-411.

Barr, W. and H. Pellett. 1972. Effect of soil temperature on growth and development of some woody plants. J. Amer. Soc. Hort. Sci. 97:632-635.

Bingham, I.J. and J.F. Farrar. 1987. Respiration of barley roots: assessment of activity of the alternative path using SHAM. Physiol. Plant. 70:491-498.

Burgos, G., J.L. Araus, and J. Azcon-Bieto. 1987. The effect of temperature on respiratory pathways of Fatsia japonica leaves, p. 389392. In: A.L. Moore and R.B. Beechey (eds.). Plant mitochondria: Structural, functional, and physiological aspects. Plenum, New York.

Cook, N.D. and R. Cammack. 1985. Effects of temperature on electron transport in Arum maculatum mitochondria. Plant Physiol. 79:332335.

Cooper, A.J. 1973. Root temperature and plant growth. Cmwlth. Bur. Hort. Plant Crops Res. Rev. no. 4. p. 1-73.

de Visser, R. and T. Blacquiere. 1984. Inhibition and stimulation of root respiration in Pisum and Plantago. Its consequences for the assessment of the alternative path activity. Plant Physiol. 75:813817.

de Visser, R., K. Spreen-Brouwer, and F. Posthumus. 1986. Alternative path mediated ATP synthesis in roots of Pisum sativum upon nitrogen supply. Plant Physiol. 80:295-300.

Dizengremel, P. and M. Chauveau. 1978. Mechanism of temperature action on electron transport in cyanide-sensitive and cyanide-resistant plant mitochondria, p. 267-274. In: G. Ducet and C. Lance (eds.). Plant mitochondria. Elsevier/North Holland Biomedical Press, Netherlands. 
Foster, W.J. 1986. Photosynthesis, respiration, and carbohydrate partitioning in Ilex crenata 'Rotundifolia' in response to supraoptimal root-zone temperatures. MS Thesis, Univ. of Florida, Gainesville.

Henry, M.F. and E.J. Nyns. 1975. Cyanide-insensitive respiration. An alternative mitochondrial pathway. Sub-Cell Biochem. 66:457-462.

Hunt, W.F. and R.S. Loomis. 1979. Respiration modelling and hypothesis testing with a dynamic model of sugar beet growth. Ann. Bet. 44:5-17.

Ingram, D.L. and D. Buchanan. 1981. Measurement of direct heat injury of roots of three woody plants. HortScience 16:769-771.

Ingram, D.L. and D. Buchanan. 1984. Lethal high temperatures for roots of three citrus rootstock. J. Amer. Soc. Hort. Sci. 109:189-193.

Janes, H.W., C-K. Chin, and J. Bachmansky. 1988. Growth and metabolism of tomato roots grown in tissue cultures held at various temperatures. HortScience 23:773.

Johnson, C.R. and D.L. Ingram. 1984 Pittosporum tobira response to container medium temperature. HortScience 19:524-525.

Kiener, C.M. and W.J. Bramlage. 1981. Temperature effects on the activity of the alternative respiratory pathway in chill-sensitive $\mathrm{Cu}$ cumis sativus. Plant Physiol. 68:1474-1478.

Lambers, H. 1982. Cyanide resistant respiration: a nonphosphorylating electron transport pathway acting as an overlfow. Physiol. Plant. 55:478-485.

Lambers, H. and D.A. Day. 1987. Respiration in intact tissues: problems and perspectives, p. 321-330. In: A.L. Moore and R.B. Beechey (eds.). Plant mitochondria: structural, functional, and physiological aspects. Plenum, New York.

Lambers. H., D.A. Day, and J. Azcon-Bieto. 1983. Cyanide-resistant respiration in roots and leaves. Measurements with intact tissues and isolated mitochondria. Physiol. Plant. 58:148-154.

Langridge, J. and J.R. McWilliam. 1967. Heat responses of higher plants, p. 232-284. In: A.H. Rose (cd.). Thermobiology. Academic, New York.

Levitt, J. 1980. Response of plants to enviromnental stresses, vol. 1. Chilling, freezing and high temperature stresses. Academic, New York.

McCaig, T.N. and R.D. Hill. 1977. Cyanide resistant respiration in wheat: cultivar differences and effects of temperature, carbon dioxide and oxygen. Can. J. Bet. 55:549-555.
McKree, K.J. 1974. Equations for the rate of dark respiration of white clover and grain sorghum as a function of dry weight, photosynthetic role and temperature. Crop Sci. 14:509-514.

Moller, I. M., A Berczi, L.H.W. van der Plas, and H. Lambers. 1988. Measurement of the activity and capacity of the alternative pathway in intact tissues: identification and problems and possible solutions. Physiol. Plant. 73:642-649.

Palta, J.A. and P.S. Nobel. 1989. Root respiration for Agave deserti: Influence of temperature, water status and root age on daily patterns. J. Expt. Bot. 40:181-186.

Penning de Vries, F.W.T. 1975. The cost of maintenance processes in plant cells. Ann. Bet. 39:77-92.

Purvis, A.C. 1988. Limitation of alternative respiratory pathway activity in grapefruit flavedo tissue by oxygen availability. Plant Physiol. 86:623-625.

Ruter, J.M. and D.L. Ingram. 1990. ${ }^{14}$ Carbon-labelled photosynthate partitioning in Ilex crenata 'Rotundifolia' at supraoptimal root-zone temperatures. J. Amer. Soc. Hort. Sci. 115:1008-1013.

Rybka, Z. 1989. Changes in the cyanide-sensitive and cyanide-resistant oxygen uptake in crowns of winter wheat seedlings during hardening to frost. J. Plant Physiol. 134:17-19.

Schonbaum, G. S., W.D. Bonner, B.T. Storey, and J.T. Bahr. 1971. Specific inhibition of the cyanide-insensitive respiratory pathway in plant mitochondria by hydroxamic acids. Plant Physiol. 47:124-128.

Spreen-Brouwer, K., T. van Halen, D.A. Day, and H. Lambers. 1986. Hydroxamate-stimulated $\mathrm{O}_{2}$ uptake in roots of Pisum sativum and Zea mays, mediated by a peroxidase. Its consequences for respiration measurements. Plant Physiol. 82:236-240.

Theologis, A. and G.G. Laties. 1978. Relative contribution of cytochrome-mediated and cyanide-resistant electron transport in fresh and aged potato slices. Plant Physiol. 62:232-237.

van der Plas, L.H.W., H. Gude, and M.J. Wagner. 1987. Hydroxamicactivated peroxidases in potato tuber callus. Interaction with the determination of the cytochrome and alternative pathways. Physiol. Plant. 70:35-45.

Wong, T. L., R.W. Harris, and R.E. Fissell. 1971. Influence of high soil temperatures on five woody-plant species. J. Amer. Soc. Hort. Sci. $96: 80-82$. 